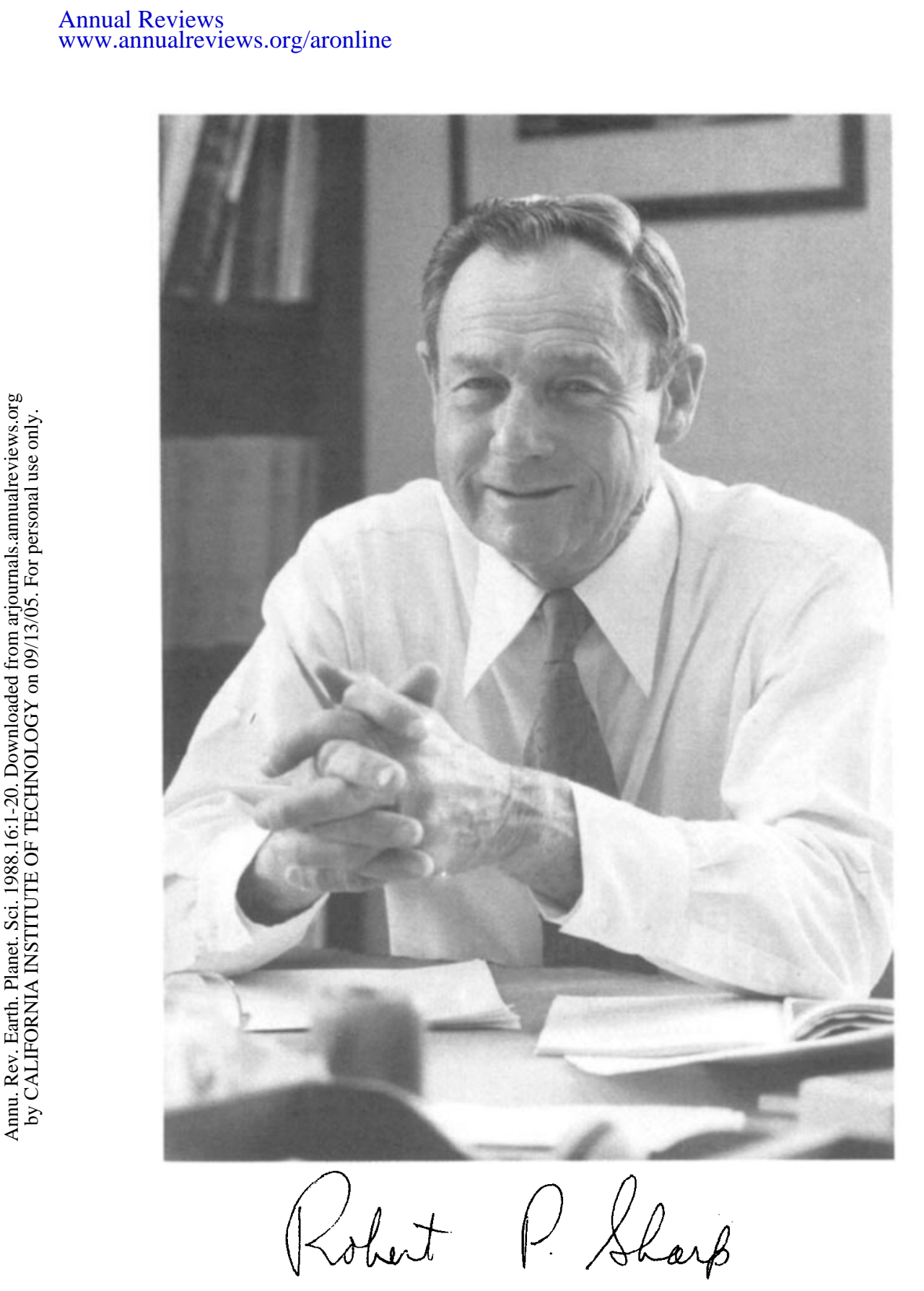




\title{
EARTH SCIENCE FIELD WORK: ROLE AND STATUS
}

\author{
Robert P. Sharp \\ Division of Geological and Planetary Sciences, California Institute of \\ Technology, Pasadena, California 91125
}

\section{Introduction}

This essay contends that the outstanding contributions currently being made to the earth sciences by theoretical and laboratory endeavors increase rather than decrease the need for sound field observations. The presentation is strongly prejudiced in favor of field studies and, accordingly, invites critical examination by skeptical minds.

Many earth science problems being investigated have their source in field studies. Samples of materials worthy of analysis by sophisticated laboratory techniques and apparatuses are selected on the basis of field studies. Furthermore, the field is where the results of theory and laboratory experimentation are tested for conformity to nature and the truth. Field investigators of all types are as sorely needed now as at any time in the past. Their role in the earth sciences merits respect and recognition.

A statement supporting field studies may seem to be championing the obvious, but Francis Pettijohn's (1984) outspoken memoirs amply demonstrate that field activities have not always been respected. Many earth scientists would profess regard for, if not devotion to, field activities, and the US Geological Survey, the greatest assemblage of earth science talent ever, is strongly field oriented. Yet many field geologists feel their discipline is on the decline, that their efforts and products are looked down upon, that time spent in field work is seen as less productive than time spent in the laboratory or before a computer, that greater and more spectacular advances are made by laboratory experimenters or theoreticians than by field workers, and that field geologists may be an endangered species.

An unusually large number of exciting earth science developments have recently come from experimental and theoretical work. Much of the 


\section{SHARP}

glamor in the earth sciences now seems to be associated with such endeavors, stimulated and supported by rapid developments in instrumentation and generous research grants. But close inspection shows that many of these fruitful advances have depended upon complementary and cooperative field investigations.

Field and laboratory work are mutually supportive, not adversative. Most field geologists need laboratory analyses to support their field work, and most laboratory investigators depend upon field data to bring reality to their studies. Few field geologists now make a career solely from field mapping, as Tom Dibblee (Steller 1986) has done so spectacularly. By the same token, few theoreticians or experimentalists proceed without reliance upon field data.

Field work may seem at times routine, unproductive, or even boring, but the same can be said of much laboratory work. One can labor long in either arena without rewarding results. Still, the chance of turning up something exciting is as great in the field as in the laboratory.

Most broadly, the term geology encompasses the study of planet Earth (Gary et al 1974, p. 293). In this sense, it includes the disciplines of geophysics, geochemistry, and geobiology (paleontology), as well as other subdisciplines involving the solid earth. A common modern practice, however, is to use the term earth science as embracing all these disciplines, including geology. This usage is followed here.

The terms field geology and field work are used in their broadest sense to include the observation, study, and investigation of natural materials, features, phenomena, and processes in their natural setting by any of a wide spectrum of procedures, techniques, and instruments. This broad concept of field work is developed fùrther in a following section. A more classical concept is based on a geologist walking out contacts between rock units and transferring data to a base map. Geological mapping, however, is only one kind of field work.

\section{Historical Perspective}

My candidate for the greatest North American geologist would be G. K. Gilbert (Pyne 1980). Gilbert was above all a field geologist. His two monumental contributions, the Lake Bonneville monograph (Gilbert 1890) and the Report on Geology of the Henry Mountains (Utah) (Gilbert 1877), are products of field work. This is not surprising, because during the 50 years of his professional career, 1869-1918, geological studies were primarily field oriented, and western United States, where Gilbert did the bulk of his work, was geologically unexplored.

In some respects, Gilbert was before his time in setting up flume experiments to study the behavior of alluvial wastes derived from California 
gold placers (Gilbert 1914). From this study he formulated some of the basic laws governing fluvial transport of coarse rock debris. Gilbert (1893) was even more adventuresome in peering through an astronomical telescope at the moon's surface. He was one of the first to look at lunar features through the eyes of a field geologist. As a result, he postulated an impact origin for lunar craters, anticipating by many years conclusions drawn by Ralph Baldwin (1949) and Harold Urey (1951). Gilbert even resorted to throwing steel ball bearings into soft mud to simulate impact features. Through such activities, he pointed the way for modern earth scientists who combine field activity and laboratory experiments (Baker \& Pyne 1978).

Outside his administrative duties for the US Geological Survey, Gilbert probably spent 80 to $85 \%$ of his research time and effort on field work and in preparing field data for publication. For many earth scientists today, laboratory effort is more likely to predominate. Modern instrumentation, techniques, and data-processing facilities make laboratory work especially productive and rewarding. As a result, fewer present-day earth scientists who devote the major part of their time and effort to field activities are regarded as outstanding by their peers, in contrast to Gilbert's time.

\section{Types of Field Work}

One's concept of field work naturally depends on special needs and interests. Near one end of the spectrum is the classical field geologist who wants to lay hands upon the earth's rocks, minerals, and fossils in their natural setting and to observe natural processes in action on the earth's surface. Such a person uses mostly eyes, feet, training, and experience in conducting field work and is likely to end up making a map showing relationships between geological units. Near the other end of the spectrum are those who employ highly sophisticated instruments, apparatuses, and techniques to learn about the physical properties, behavior, and relationships of masses composing the earth that cannot be ascertained by direct visual observation. The objective of such studies often lies within the earth rather than on its surface. Between these extremes is a wide variety of tasks, such as collecting specimens, measuring stream velocity, operating tiltmeters, and detailing stratigraphic sections.

Most exploratory geophysical procedures are forms of remote sensing, which does not at first thought seem like field work. Seismology, magnetometry, and gravimetry are examples. When Vening-Meinesz (1948) boarded a Netherlands submarine planning to operate a gravity meter over ocean basins, he actually embarked on a field program. If a magnetometer is used by someone walking over the ground, its measurements would probably be accepted as a product of field work. Why not regard 
measurements made by the same magnetometer flown over the area in an aircraft as the product of field work? If a geologist charters a plane for one day to fly over an area being mapped, has that day been devoted to something other than field work? Most of us would think not. The same geologist may make liberal use of aerial photos for mapping without thinking of them as a product of remote sensing.

A wide array of geophysical techniques is used for probing the earth, and if one, such as magnetometry, qualifies as field work, why not similarly regard the others? Geophysical techniques are used to observe and record characteristics of the earth in its natural state, whether the instruments are carried by hand, car, boat, submarine, airplane, spacecraft, or donkey. In most instances, field data not available in any other way are gathered by techniques of remote sensing. The fact that a remote-sensing technique, such as shuttle imaging radar in North Africa (Elachi et al 1982), benefits from subsequent ground studies (McCauley et al 1982) does not make it any less a form of field work. To map mantle tomography by use of earthquake waves, without ever leaving the laboratory, is in the broadest sense also a type of field work.

Remote sensing has the virtue of providing integrated views of largescale relationships. Its needs have stimulated the development of techniques, instruments, and procedures that make possible more effective scientific observation of our Earth. It seems high time to recognize that remote sensors are engaged in an important form of field activity.

Essentially everyone accepts geological field mapping as classical field work. Two easily identified types of mapping are exploratory and directed. Exploratory mapping is carried on primarily to discover what exists within areas of unknown terrane. It is widely practiced in government and industry, and by some individuals. Exploratory mapping raises more questions than it answers, because by reconnaissance it turns up many new and unexpected findings. Directed mapping is normally conducted to solve specific problems or to support other field activity. It is normally more detailed but of more limited scope, both geographically and intellectually, than exploratory mapping, and it is designed to produce answers. To a purist, geological mapping of either type is the most basic form of field work.

Direct observations of geological phenomena in action, such as floods, surging glaciers, and volcanic eruptions, are productive and excitingeven hazardous - types of field work. Underground mapping in mines is a specialized activity largely of commercial interests. Although field geologists tend to rely on natural exposures, modern earth-moving tools, such as backhoes, are now often employed by Quaternary geologists, in place of shovels, to make artificial exposures at critical sites. 
A widely exercised type of field activity is what might be called "showand-tell." This is a procedure in which persons who have conducted field studies of relationships in a specific location show them to others and present explanations and interpretations. Show-and-tell field trips, usually sponsored by organizations, are an effective way of sharing knowledge.

Field work involves the observation, visual or instrumental, of natural materials and processes of the earth in their natural setting. Sometimes the only workable means are by the techniques of remote sensing. Defined this broadly, field work is done far more extensively by earth scientists than they or others may realize.

\section{Field Work as Related to Research}

Field activity introduces reality into earth science research. Nature can be a harsh critic, destroying elegant theoretical models with a few hard, cold facts. It makes sense to base such models on as much salient, sound field data as possible. No matter how attractive, a theoretical product remains incomplete until shown to be compatible with field relationships. Successful theoreticians respect and value field data and do not hesitate to enlist the cooperation of field workers in obtaining more. Essentially the same can be said for laboratory experimentation.

Much modern analytical equipment is so productive that one has to guard against letting the satisfaction of doing laboratory procedures overwhelm the significance of the analyses. Time and resources can be wasted analyzing specimens that do not merit the effort and expense. Since the earth sciences deal with complex, messy systems, a large number of relatively imprecise data are often more useful than a few highly precise values. There is little point in measuring the width of a city street to fractions of a millimeter with a micrometer. Field work is relatively inexpensive compared to most laboratory procedures, so it makes sense to invest in a thorough field study before launching an expensive analytical program. Contrariwise, in some situations, a few blind laboratory analyses may be required to establish the need for detailed field work.

A good field map is a necessity for many earth science research projects (US Geological Survey 1987, Reinhardt \& Miller 1987). Such a map may have already been made, or it can be custom made, perhaps by someone other than the principal investigator. The problem being investigated may even have been identified in the first place by mapping. Geological knowledge of the area will help any research program, no matter how specialized or localized, to avoid later surprises.

Not all earth scientists need be adept at field mapping, but awareness of its value is desirable, as has been demonstrated many times. Consider the Heart Mountain overthrust of Wyoming, which for many years after 
its initial description (Hewitt 1920) was regarded as a rooted thrust produced by compression in the crust. Years of detailed field work by William G. Pierce $(1941,1957,1960,1963,1973,1979)$ were required to demonstrate that the Heart Mountain structure is a detachment thrust, essentially a huge slide, originating in the northeast corner of Yellowstone Park. The field relationships are striking, but a program of devoted mapping over a large region was required to demonstrate their true meaning.

Some geological settings allow us to observe and monitor experiments being conducted by nature at real scales in natural environments. Tracking natural experiments has yielded good results for rapidly acting processes and agents, such as glaciers, rivers, volcanism, wind, tectonism, and shoreline activities. Working with such situations requires patience, sometimes for years, before useful results are obtained, and even then it can be frustrating. Nature has a habit of changing parameters and variables indiscriminately at inopportune moments. Because of their duration and attending uncertainties, many natural experiments are not suitable subjects for graduate student research; they lie more in the domain of established professionals with a stable base.

\section{Pedagogical Value of Field Work}

The first geological field experience of many people is likely to be a showand-tell field trip (Figure 1). Such trips are effective for stimulating interest among nonprofessionals and attracting the attention of other scientists to the opportunities and satisfactions of working on geological problems.

Show-and-tell can generate interest in the earth sciences without a large investment of time and effort on the part of nongeologists. Something seen in its natural state arouses more enthusiasm than it does through the medium of written or photographic representation, and it is certainly better retained in memory. Through stimulation by show-and-tell experiences, physicists, chemists, and planetary scientists, among others, have actually become professional earth scientists. It is a rewarding experience to have a radio astronomer wax enthusiastic about geological field phenomena after participating in some show-and-tell experiences. This has happened more than once. The show-and-tell procedure sows seeds widely, and one never knows what may sprout from some unexpected spot.

As a purely pedagogical procedure, show-and-tell has limitations in not demanding enough from the audience (students). Its educational function can be enhanced by presenting problems and challenges that require audience participation. The emphasis can be on show, with students providing the tell.

Educational insitutions could use field experiences more effectively in 
elementary geology courses by designing self-guided field excursions to replace some of the indoor exercises of the usual physical geology laboratory. This works better in some environments than others, but even the polished slabs of granite and gneiss in the local village bank front, the glacial erratic in the quad fronting the library, the cut behind the bookstore, or the gully and stream through the arboretum can, with imagination and thought, be used as a basis for field observation and interpretation by students. Send students into the field with written descriptive guides and thought-provoking questions. Don't lead them by the hand. It is also probably more effective to send them back into the field alone, with a corrected exercise in hand, than to conduct them en masse for a review of relationships.

Participation in a full-fledged field project is a still more effective means of generating a commitment to the earth sciences, on the part not only of students but of scientists from other disciplines. The British seem to practice this with particular success. Take, for example, Gerald Seligman's (1941) Jungfraujoch research program in glaciology, which enlisted the talents of Nobel laureate-to-be Max Perutz (Perutz \& Seligman 1939), among others. Similar results attended a program of field research on the Austerdalsbrea in Norway, which led to major glaciological contributions from British physicists John Nye $(1952,1960,1963)$ of Bristol and John Glen $(1955,1956)$ of Birmingham.

Geological field mapping may be regarded by the uninitiated as a simpleminded task of putting lines on maps. In truth, it is a first-class pedagogical discipline requiring keen observation, synthesis, and interpretation. Learning to arrive at workable conclusions, often on the basis of insufficient evidence, is part of the art of doing both geology and field mapping. Field mapping demands decisions; otherwise the map remains blank. Any reasonably intelligent person can be trained to do geological mapping, but as with many other pursuits, really good field mappers seem to be born, not made. The knack is not given to everyone, and those who have it deserve to be nurtured and respected.

Nature is a perverse ego humbler, and she exercises that trait freely in field geology. She delights in throwing spitball curves that send the overconfident neophyte, and often the hardened, experienced field mapper, back to the dugout muttering to themselves.

Except in the simplest areas, mapping involves a steady flux of surprises and complications. It is a detective game, solving ancient crimes committed by nature, with the clues now obscured. The experience is good for students. One of the main goals of a college education should be to establish a discipline of self-education. Few places are better suited to do that than the field. Nature is a stern teacher. 
A Annual Reviews

R www.annualreviews.org/aronline

8 SHARP
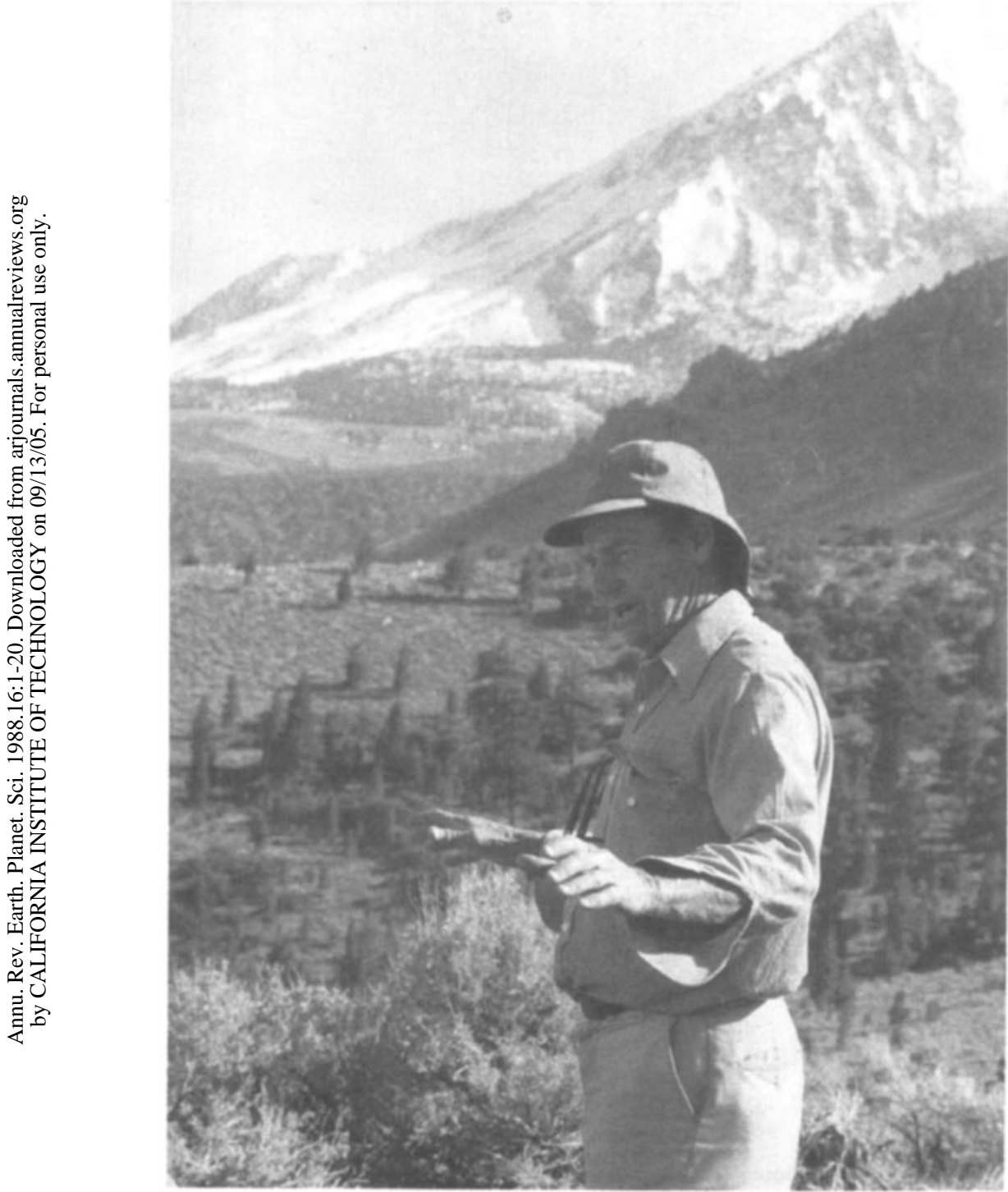

Figure 1 (above and facing) Sharp and students during a field excursion east of the Sierra Nevada in the early 1980s devoted to inspection of glacial features. 


\section{A Annual Reviews \\ R www.annualreviews.org/aronline}
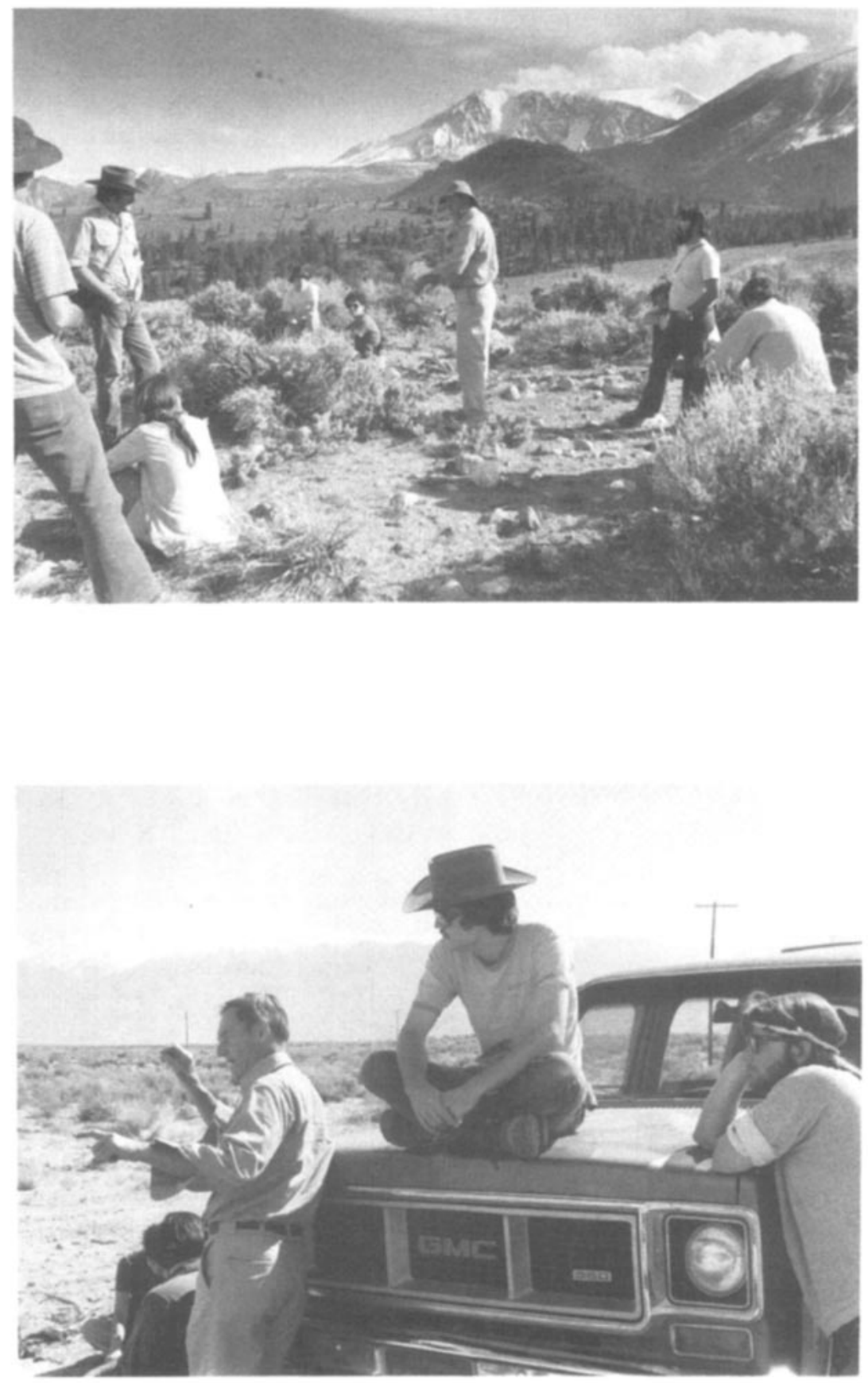


\section{Special Projects Related to Field Work}

At least two long-range communal projects could be initiated by field geologists for the benefit of future generations of earth scientists.

THE CENTURY PROJECT A central committee of retired field workers could be formed under the auspices of one of our national earth science organizations. This committee would design, select, and implement a number of field experimental and observational projects aimed at determining the rates at which geological changes take place over a period of 100 years.

Initiators of the program would obviously derive no direct benefit from it, hence the emphasis on older, retired people, who presumably have arrived, at least intellectually, and can afford to be generous with their time and effort. Raising funds for the project would be the responsibility of the central committee, which would also be charged with seeing that monitoring was maintained. The committee would have to be a continuing body with a slowly changing membership, managed by the sponsoring organization.

Suggestions for experiments should be solicited nationwide, and a selection of the most desirable, that could be adequately financed, would be made by the committee or a panel operating under its auspices. The central committee would assign responsibility for installation and periodic monitoring of each experiment, probably most often to the originators of the accepted proposals. For each experiment, the responsible entity would be charged with seeing that the baton of maintenance and monitoring was passed along to assure continuity to the completion of the project. Periodic reviews of each experiment by the central committee should be made to assure continuity.

Reports could be prepared periodically by experimenters, and the central committee could issue summaries through publication or other means, with ample credit to individuals. In 100 years, a final report on each experiment would be published under auspices of the central committee with full credit to all who participated.

Monitoring already going on in fields such as volcanology, glaciology, and neotectonics would not be duplicated. The types of experiments considered, all in natural settings, might include sedimentation rates for deposits in various environments, weathering and erosion rates, slow massmovements, ground-ice wasting, dune migration, clay and caliche accumulation in soils, groundwater deposition, and shoreline modifications. There is no dearth of things that might be done. The task would be to select feasible experiments, likely to produce meaningful results, that could be maintained and monitored at reasonable cost and effort over a century.
A CENTER FOR FIELD TRIP GUIDEBOOKS Unfortunately, much excellent 
field information is never published except in road logs and guides for field trips associated with a one-time event. The amount of valuable information packed away in such media is huge, but it is not easily accessible.

Field trip guides are issued by a number of widely dispersed sponsoring organizations; only a limited number are part of established serial publications. Guidebooks are commonly printed in small numbers, as special publications, and rapidly become unavailable. Few libraries have more than a sampling of field guides, and those they do have are a headache because of classification.

The Guidebooks Committee of the Geosciences Information Society has compiled a splendid catalog of geological field trip guidebooks of North America, up to 1980 , and a limited listing of library holdings. A fourth edition of their catalog has recently been published by the American Geological Institute (1986). This is a commendable accomplishment, but more is needed.

Someone with library skills, organizational sense, and entrepreneurial spirit could render a major service to the earth sciences, hopefully at a profit, by establishing a Center for Field Trip Guidebooks. The Center should search out and assemble single copies of every field guide that can be located. Frequently, updated lists of these holdings should be distributed.

Through arrangements with authors and publishers, permission should be obtained allowing the Center to reproduce and sell copies of the guides at a price designed to support the Center's operation and provide a profit. If some tax-exempt organization undertook the service, it could be operated more economically on a no-gain basis and initial outlays might be underwritten by grants.

\section{Personal Experiences}

Field geology can be done almost anywhere at any time, with no more equipment than a notebook and pencil, by anyone with reasonable training and experience. Furthermore, it is usually worth doing. The following personal experiences are offered to illustrate the point.

In the summer of 1937, while finishing field work on a $\mathrm{PhD}$ thesis on geology of the Ruby-East Humboldt Mountains of northeastern Nevada (Sharp 1939), I began getting letters from Ian Campbell at the California Institute of Technology exploring possibilities of my joining a geological boat expedition through the Grand Canyon in October and November. The purpose of the expedition was to study exposures of the Archean igneous-metamorphic complex within the inner gorges, which are hard to reach except from river level. The expedition was to be jointly sponsored by Caltech and the Carnegie Institution. 


\section{SHARP}

That arrangement came about because John C. Merriam, famed vertebrate paleontologist at the University of California (Berkeley), had become Director of the Carnegie Institution of Washington. He wished to see the geology of the Grand Canyon thoroughly studied. Aside from early explorations, largely by Powell (1875), Gilbert (1875), Dutton (1882), and Walcott $(1883,1890,1894,1895)$, modern work had focused primarily on the Paleozoic (McKee 1934, 1938, Wheeler \& Kerr 1936) and Proterozoic rocks (Van Gundy 1934, Hinds 1935). The only published product of comprehensive field mapping in the canyon was Levi Noble's (1914) excellent bulletin on the Shinumo quadrangle, which lies west of that part of the national park normally visited by tourists.

Solomon-like, Merriam apportioned the Paleozoic section to E. D. McKee, then ranger naturalist of the National Park Service, later of the US Geological Survey; the Proterozoic sedimentary and volcanic rocks to N. E. A. Hinds of the University of California (Berkeley); and the Archean complex to Ian Campbell and John H. Maxson of Caltech. Merriam supported these investigators with financial grants and facilitated publication of results in Carnegie Institution monographs (McKee 1934, 1938, McKee \& Resser 1945, Hinds 1935).

Thus, I found myself in earliest October 1937 at Lee's Ferry on the Colorado River in the company of three experienced boatmen and three senior geologists - Campbell, Maxson, and J. T. Stark of Northwestern University. We were to board three wooden Stone-Galloway river boats for a two-month voyage of 280 miles through the Grand Canyon into Lake Mead, then filling behind Boulder (Hoover) Dam. McKee later joined the party at the foot of the old Bass Trail, partway along our route.

In 1937, the Colorado River was not a tourist's run; probably less than 100 people had made the trip through the canyon. Only one professional geologist other than Powell was known to have preceded us on such a voyage: Raymond C. Moore (1925), Professor of Geology at the University of Kansas and Kansas State Geologist, was a member of the 1923 Birdseye expedition (LaRue 1925) sponsored by the US Geological Survey to locate and evaluate dam sites.

Our expedition was truly exploratory with a promise of scientific discovery. I was very much the junior member of the group, and why Campbell took me rather than an experienced igneous-metamorphic petrologist, I'll never know. We traveled as fast as conditions, mostly rapids, permitted in reaches through Paleozoic and Proterozoic rocks and more slowly within the inner-gorge Archean exposures.

I asked Campbell if he had any specific geological chores in mind for me, and he decided I should keep track of pegmatite bodies in the Archean terrane. This and other activities did not fully occupy my time, so I cast 
around for something to do on my own. The Paleozoic belonged to McKee, the Proterozoic to Hinds, and the Archean to Campbell and Maxson, so I had to find something in between to avoid stepping on toes. Two great uncomformities are spectacularly exposed in the canyon walls: the younger one at the base of the Paleozoic beds where they rest upon truncated Proterozoic strata or the Archean complex, and the older one separating Proterozoic beds from truncated Archean rocks.

These appeared to fill the bill nicely. The near-horizontal pre-Paleozoic surface is exposed in cross section in the canyon walls along the wandering course of the river and its tributaries, so one gets a reasonable view of its three-dimensional relief. The pre-Proterozoic surface is preserved only in tilted fault blocks scattered throughout the region, so it is not so completely exposed. The study had to be improvised without a literature search or preconceived ideas. I had a Brunton compass, geological hammer, pencil, and notebook. Modern US Geological Survey topographic maps were available for only two or three quadrangles along the entire extent of the canyon, but river profile maps from the Birdseye work were helpful.

My improvised project meant some inconvenience for others of the expedition. Most of their work was conducted from daytime stops along the river, rather than from established camps. When a stop was made, if at all feasible I took off up a tributary canyon to get a look at one of my unconformities. As a result, when the rest of the party was prepared to move on, Sharp was often 500 to 1000 feet above on the CambrianArchean contact and out of touch. Nonetheless, Campbell was remarkably patient and supportive in letting me pursue my project.

The unconformities were produced by uplift and subsequent terrestrial erosion and weathering over hundreds of millions of years. Both of them retained remnants of the regolithic mantle produced on and within the underlying rocks. This weathering and erosion had occurred on a landscape devoid of vegetative cover under oxidizing conditions. The ancient erosion surfaces were each subsequently slowly invaded by a shallow sea, and the regolith had clearly been reworked into the basal layers of the initial marine sediments (Sharp 1940a). Striking sea cliffs were cut into residual knobs on the pre-Paleozoic surface by waves of the encroaching Cambrian sea. Looking at cross-section exposures of such cliffs in the canyon walls, one can almost hear the roar of the Cambrian surf hurling itself against the cliff and retreating to gather strength for its next attack. The knobs, with their sea cliffs flanked by outward-thinning tongues of coarse, reworked debris, were eventually submerged by the ever-deepening water, and ultimately buried by finer seafloor deposits.

In one locality, a cuesta on the pre-Paleozoic surface, created by subaerial erosion of tilted layers of Proterozoic quartzite, had been undercut 


\section{SHARP}

by waves, generating a huge rockslide that spread outward over the seafloor across earlier beds of fine sediment. The slide contorted these beds into convolutions and whorls and created a tongue of coarse, angular quartzite breccia (Sharp 1940b).

The opportunity to work with these relationships was a stimulating scientific adventure for a neophyte geologist. The Grand Canyon voyage alone would have been a great adventure through magnificent scenery. Thanks to the ease with which one can do field geology, it was an enriching intellectual experience for me.

In late 1940 and early 1941, as a young faculty member at the University of Illinois, I received communications from Walter A. Wood, Director of Exploration and Field Research at the American Geographical Society in New York City, telling of explorations he and others had been conducting for years in the remote Mt. Steele and Wolf Creek (later renamed Steele Creek) area in the ice-bound St. Elias Range along the Yukon-Alaska border. Wood, trained as a geodesist in Switzerland, was using modern Swiss techniques to set up a triangulation network in this unsurveyed region.

Would I be interested in joining the expedition as a geologist, doing whatever I wished in the way of field work? My early wanderings in California's Sierra Nevada and mapping of glacial features in the RubyEast Humboldt Range of Nevada (Sharp 1938) had whetted my interest in glaciers. The invitation to become familiar with active ice bodies was irresistible, and the summer's experience led to subsequent glaciological work extending over twenty years.

Although the Mt. Steele project allowed greater preparation than the Grand Canyon exercise, I was working entirely by myself with minimal equipment; the only special items were a Swedish increment borer for coring trees and a small ROTC tripod and plane table for mapping. No base maps were available, but Wood's triangulation network proved useful. The only paths were game trails made by Dall sheep and grizzly bears. The bears repeatedly devastated our caches of canned goods, except for an early version of the Army C-ration, which they disdainfully rejected.

It was a productive and educational summer of new experiences with glaciers (Sharp 1947), bedrock (Sharp 1943), frozen ground and ground ice (Sharp 1942c), debris flows (Sharp 1942a), and patterned ground (Sharp 1942b). A lot can be learned in two and a half months doing field work in a virgin area. I didn't have the background, however, to realize that the stagnant condition of the lower few kilometers of Wolf Creek (Steele) glacier showed it had undergone an earlier episode of surging. Twenty-five years later, in 1965-66, the glacier surged again, rejuvenating its stagnant lower reach (Post 1969, p. 230). 
During World War II, as part of an Army-Air Force intelligence unit dealing with arctic, desert, and tropic environments, I was in the Aleutians during the summer of 1945 working on survival problems for the Eleventh Air Force. In the course of this duty, a visit to Shemya, the third westernmost island of the Aleutian chain, brought me to a firm-minded general who said, "I don't believe all this junk you fellows write about survival in this area. Let's put you over on Agattu for a few days and see how you do." So a small speedboat deposited me on the east coast of Agattu with a sleeping bag and the meager bailout kit of a single-seater fighter pilot. They kindly gave me a cup of coffee before putting me ashore.

Even in summer, the Aleutians are cool and damp. I had matches, but the Aleutian tundra provides little fuel, and shoreline driftwood is meager and wet. A small cooking fire was possible, but not a warming fire. I would have appreciated the pilot's parachute, but that was not available because I had not bailed out. Some shelter from light rains and mist was obtained beneath a stream-cut bank capped by tundra.

Food proved to be no problem. The bailout kit contained a line and fishhooks. Within the first day, I caught enough small arctic char out of a stream to feed myself and a friendly gray fox for days. Sea urchins were plentiful along shore, and their roe is extremely nutritious, but it proved too rich for my stomach without blander foods. Chitons and small mussels were abundant, and edible plants could be found within the complex of tundra vegetation.

Once settled in and tired of watching puffins and whales, I explored coastal cliffs in search of a cave for shelter. Instead, I soon found extensive, modestly inclined exposures of thinly bedded, light-colored, siliceous sedimentary rocks some 600 meters thick (Sharp 1946). I was flabbergasted. The Aleutians are known to be an island arc, a chain of volcanic cones. What were sedimentary rocks like these doing on Agattu?

A literature search later revealed that other small accumulations of sedimentary rocks were known in the islands, and more may have been discovered since. The Agattu rocks proved to be porcellanites, presumably formed by silicification of fine-grained pyroclastics, so they were at home in a volcanic province, although they reflected an unusual environment of accumulation.

I was elated by the discovery. This was the one occasion during the war when I could do a bit of geology, albeit solely with notebook and pencil. An isotopic geochemist might have found Agattu uninteresting and forbidding. To a field geologist, it was fascinating.

When plans were formulated for experiments to be carried aboard spacecraft Mariners 3 and 4, during a flyby of Mars in 1965, Caltech physicist R. B. Leighton, designer and principal experimenter for the 
television camera, realized that pictures of the martian surface needed to be studied by a geologist, so he drafted Bruce Murray of Caltech's geology division. Murray recognized that the pictures would show primarily landscape features, so he drafted geomorphologist Sharp, and we three constituted the TV scientific team. Craters and faults proved to be the two primary forms shown on the 22 photos taken by Mariner 4. (Mariner 3 had shroud troubles and never got out of Earth orbit.)

This early work led to further participation in the Mariner 6 and 7 flybys and the Mariner 9 orbiter, which produced many good photos of martian surface features. Extensive experience in field work on Earth was an invaluable background for interpreting the martian terrains.

I have been fortunate to participate as a colleague in modern geochemical stable isotope research (Epstein \& Sharp 1959) and in planetary science projects (Sharp 1973), largely because as a classical, old-time field geologist, I could bring something useful to the investigations.

\section{Conclusion}

Are field geologists an endangered species? Only if they themselves think so and behave accordingly.

As the earth sciences use more sophisticated laboratory procedures and theoretical models, the need for good field data increases rather than decreases. The relationship is symbiotic: The field and laboratory need each other, and as one prospers, the other benefits. Not everyone need be a field geologist, but the earth sciences will advance more effectively if workers use and have respect for field data and those who produce it. The earth sciences will always need people who are skilled at making field observations.

\section{Literature Cited}

American Geological Institute. 1986. Union List of Geologic Field Trip Guidebooks of North America. 200 pp. 4th ed.

Baker, V. C., Pyne, S. 1978. G. K. Gilbert and modern geomorphology. Am. J. Sci. 278: 97-123

Baldwin, R. B. 1949. The Face of the Moon. Chicago: Univ. Chicago Press. $238 \mathrm{pp}$.

Dutton, C. E. 1882. Tertiary history of the Grand Canyon district. US Geol. Surv. Monogr. 2. 264 pp.

Elachi, C., Brown, W. E., Cimino, J. B., Dixon, T., Evans, D. L., et al. 1982. Shuttle imaging radar experiment. Science 218: 996-1003

Epstein, S., Sharp, R. P. 1959. Oxygen isotope variations in the Malaspina and Saskatchewan glaciers. J. Geol. 67: 88-102
Gary, M., McAfee, R., Wolf, C. L., eds. 1974. Glossary of Geology. Washington, DC: Am. Geol. Inst. 805 pp.

Gilbert, G. K. 1875. Report on the geology of portions of Nevada, Utah, California, and Arizona examined in the years 1871 and 1872. US Geogr. Geol. Surv. W. of the 100th Meridian Rep. 3: 17-187

Gilbert, G. K. 1877. Report on the Geology of the Henry Mountains. Washington, DC: US Geogr. Geol. Surv. Rocky Mtn. Reg. 2nd ed. (1880). 160 pp., 170 pp.

Gilbert, G. K. 1890. Lake Bonneville. US Geol. Surv. Monogr. 1. $438 \mathrm{pp}$.

Gilbert, G. K. 1893. The moon's face; a study of the origin of its features. Philos. Soc. Washington Bull. 12: 241-92

Gilbert, G. K. 1914. The transportation of 
debris by running water. US Geol. Surv. Prof. Pap. 86. 263 pp.

Glen, J. W. 1955. The creep of polycrystalline icc. Proc. R. Soc. London Ser. A 228: $519-38$

Glen, J. W. 1956. Measurement of the deformation of ice in a tunnel at the foot of an ice fall. J. Glaciol. 2: 735-45

Hewitt, D. F. 1920. The Heart Mountain overthrust, Wyoming. J. Geol. 28: 536-57

Hinds, N. E. A. 1935. Ep-Archean and EpAlgonkian intervals in western North America. Carnegie Inst. Washington Publ. $463.52 \mathrm{pp}$.

LaRuc, E. C. 1925. Water power and flood control of Colorado River below Green River, Utah. US Geol. Surv. Water Supply Pap. 556. $171 \mathrm{pp}$.

McCauley, J, F., Schaber, G. G., Breed, C. S., Grolier, M. J., Haynes, C. V., et al. 1982. Subsurface valleys and geoarcheology of the eastern Sahara revealed by shuttle radar. Science 218: 1004-20

McKee, E. D. 1934. The Coconino sandstone-its history and origin. Carnegie Inst. Washington Publ. 440, 7: 77-115

McKee, E. D. 1938. The environment and history of the Toroweap and Kaibab formations of northern Arizona and southern Utah. Carnegie Inst. Washington Publ. $492.268 \mathrm{pp}$.

McKee, E. D., Resser, C. E. 1945. Cambrian history of the Grand Canyon region. Carnegie Inst. Washington Publ. 563, pp. 3 168

Moore, R. C. 1925. Geologic report on the inner gorge of the Grand Canyon of Colorado River. US Geol. Surv. Water Supply Pap. 556, pp. 125-71

Noble, L. F. 1914. The Shinumo quadrangle, Grand Canyon district, Arizona. US Geol. Surv. Bull. $549.100 \mathrm{pp}$.

Nye, J. F. 1952. The mechanics of glacier flow. J. Glaciol. 2: 82-93

Nye, J. F. 1960. The response of glaciers and ice sheets to seasonal and climatic changes. Proc. R. Soc. London Ser. A 256: 559-84

Nye, J. F. 1963. On the theory of the advance and retreat of glaciers. Geophys. J. R. Astron. Soc. 7: 431-56

Perutz, M. F., Seligman, G. 1939. A crystallographic investigation of glacier structure and the mechanism of glacier flow. Proc. R. Soc. London Ser. A 172: 335-60

Pettijohn, F. J. 1984. Memoirs of an Unrepentant Field Geologist: A Candid Profile of Some Geologists and Their Science. Chicago: Univ. Chicago Press. $260 \mathrm{pp}$.

Pierce, W. G. 1941. Heart Mountain and South Fork thrusts, Park County, Wyoming. Am. Assoc. Pet. Geol. Bull. 25: 202145
EARTH SCIENCE FIELD WORK

Pierce, W. G. 1957. Heart Mountain and South Fork detachment thrusts of Wyoming. Am. Assoc. Pet. Geol. Bull. 41: 591626

Pierce, W. G. 1960. The "break-away" point of the Heart Mountain detachment fault in northwestern Wyoming. US Geol. Surv. Prof. Pap. 400-B, pp. 236-37

Pierce, W. G. 1963. Reef Creek detachment fault, northwestern Wyoming. Geol. Soc. Am. Bull. 74: 1225--36

Pierce, W. G. 1973. Crandall Conglomerate, an unusual stream deposit and its relation to Heart Mountain faulting. Geol. Soc. Am. Bull. 84: 2631-44

Pierce, W. G. 1979. Clastic dikes of Heart Mountain fault breccia, northwestern Wyoming, and their significance. US Geol. Surv. Prof. Pap. 1133. 25 pp.

Post, A. 1969. Distribution of surging glaciers in western North America. J. Glaciol. 8: $229-40$

Powell, J. W. 1875. Exploration of the Colorado River and Its Canyons. New York: Dover. $400 \mathrm{pp}$.

Pyne, S. J, 1980. Grove Karl Gilbert: A Great Engine of Research. Austin: Univ. Tex. Press. 306 pp.

Reinhardt, J., Miller, D. M. 1987. Cogeomap: a new era in cooperative geologic mapping. US Geol. Surv. Circ. 1003. 12 pp.

Seligman, G. 1941. The structure of a temperate glacier. Geogr. J. 97: 295-315

Sharp, R. P. 1938. Pleistocene glaciation in the Ruby-East Humboldt Range, northeastern Nevada. J. Geomorph. 1:296 323

Sharp, R. P. 1939. Basin-range structure of the Ruby-East Humboldt Range, northeastern Nevada. Geol. Soc. Am. Bull. 50: 881-919

Sharp, R. P. 1940a. Ep-Archean and EpAlgonkian erosion surfaces, Grand Canyon, Arizona. Geol. Soc. Am. Bull. 51: $1235-69$

Sharp, R. P. 1940b. A Cambrian slide breccia, Grand Canyon, Arizona. Am. J. Sci. 238: 668-72

Sharp, R. P. 1942a. Mudflow levees. $J$. Geomorph. 5: 222-27

Sharp, R. P. 1942b. Soil structures in the St. Elias Range, Yukon Territory. $J$. Geomorph. 5: 274-301

Sharp, R. P. 1942c. Ground-ice mounds in tundra. Geogr. Rev. 32: 417-23

Sharp, R. P. 1943. Geology of the Wolf Creek area, St. Elias Range, Yukon Territory, Canada. Geol. Soc. Am. Bull. 54: 625-49

Sharp, R. P. 1946. Note on the geology of Agattu, an Aleutian Island. J. Geol. 54: 193-99

Sharp, R. P. 1947. The Wolf Creek glaciers, 


\section{SHARP}

St. Elias Range, Yukon Territory. Geogr. Rev. 37: 26-52

Sharp, R. P. 1973. Mars: fretted and chaotic terrains. J. Geophys. Res. 78: 4073-83

Stellar, D. L. 1986. Thomas Wilson Dibblee, Jr. Calif. Geol. 39: 202-6

Urey, H. C. 1951. The origin and development of the earth and other terrestrial planets. Geochim. Cosmochim. Acta 1: 209-77

US Geological Survey. 1987. National Geologic Mapping Program. US Geol. Surv. Circ. 1020.29 pp.

Van Gundy, C. E. 1934. Some observations on the Unkar group of the Grand Canyon Algonkian. Grand Canyon Nat. Notes 9: 33849

Vening-Meinesz, F. A. 1948. Gravity Expeditions at Sea 1923-1938. Delft: Publ.
Neth. Geod. Comm. 4. 233 pp.

Walcott, C. D. 1883. Pre-Carboniferous strata in the Grand Canyon of the Colorado, Arizona. Am. J. Sci. 26: 437-42

Walcott, C. D. 1890. Study of a line of displacement in the Grand Canyon of the Colorado, in northern Arizona. Geol. Soc. Am. Bull. 1: 49-64

Walcott, C. D. 1894. Pre-Cambrian igneous rocks of the Unkar terrane, Grand Canyon of the Colorado, Arizona. US Geol. Surv. Ann. Rep. 14, pt. 2, pp. 497-524

Walcott, C. D. 1895. Algonkian rocks of the Grand Canyon of the Colorado. J. Geol. 3: $312-30$

Wheeler, R. B., Kerr, A. R. 1936. Preliminary report on the Tonto Group of the Grand Canyon, Arizona. Grand Canyon Nat. Hist. Assoc. Bull. 5: 1-16 
Annual Reviews

www.annualreviews.org/aronline

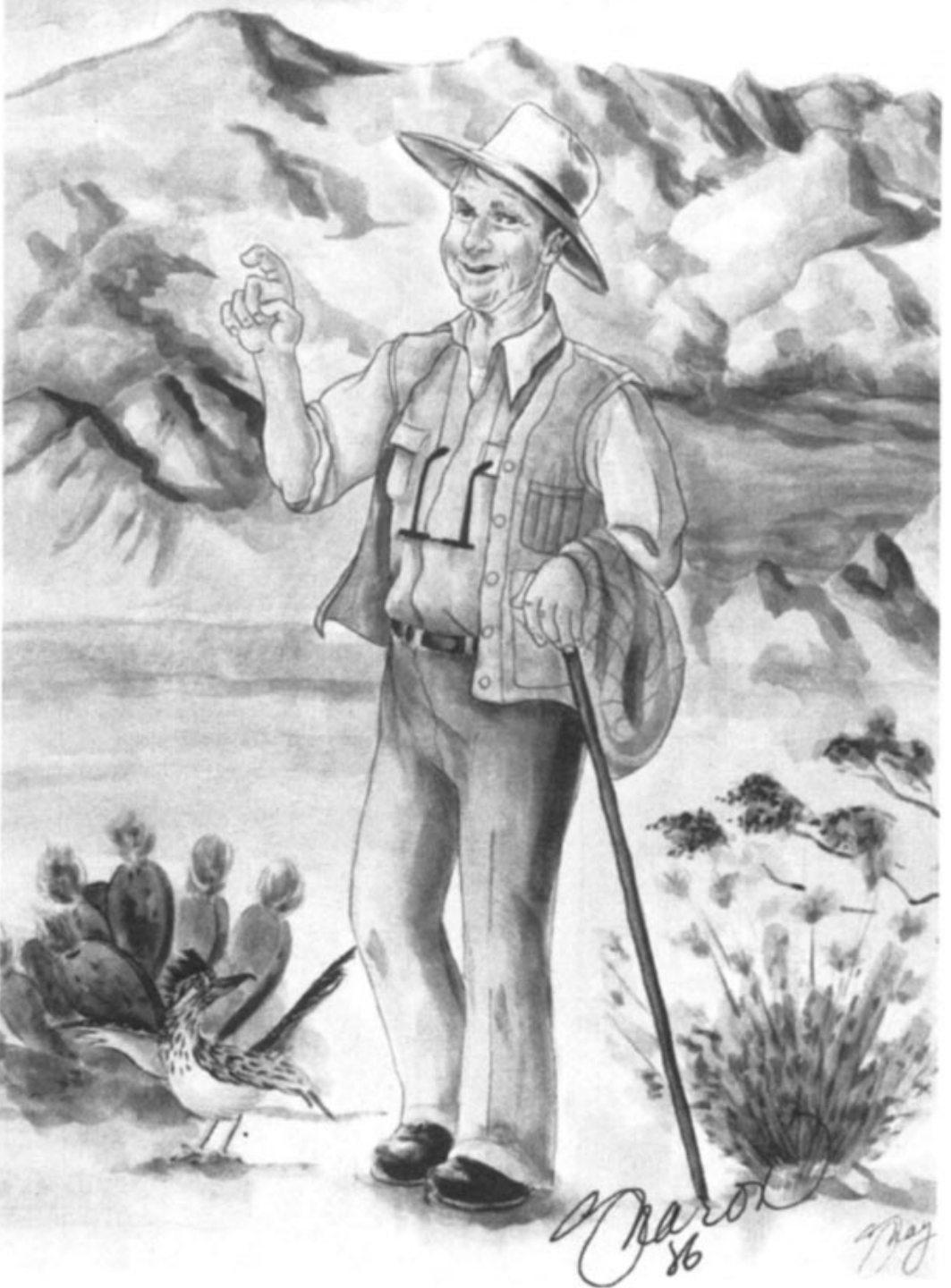

Photo of near-life-size caricature of Bob Sharp in the field, complete with staff and Filson jacket, as created in 1986 by Sharon Martens, emphasizing a characteristic gesture being imitated by the roadrunner, one of Bob's favorite birds. 
A Annual Review of Earth and Planetary Sciences

R Volume 16, 1988

\section{CONTENTS}

Earth Science Field Work: Role and Status, Robert P. Sharp 1

Phase Relations of Peraluminous Granitic Rocks and Their Petrogenetic Implications, E-an Zen 21

Chondritic Meteorites and the Solar Nebula, John A. Wood 53

VolCaniC WINTERS, Michael R. Rampino, Stephen Self and Richard B. Stothers

Mass Wasting on Continental Margins, J. M. Coleman and D. B. Prior

101

EARTHQUake Ground Motions, Thomas H. Heaton and Stephen H. Hartzell

Ore Deposits as Guides to Geologic History of the Earth, C. Meyer

Geology of High-Level Nuclear Waste Disposal, Konrad $B$. Krauskopf

Tectonic Evolution of the CaribBean, Kevin Burke

The Earth's Rotation, John M. Wahr

The Geophysics of a Restless Caldera-Long Valley, California, John B. Rundle and David P. Hill

Observations of Cometary Nuclei, Michael F. A'Hearn

The Geology of Venus, Alexander T. Basilevsky and James $W$. Head, III

Seismic Stratigraphy, Timothy A. Cross and Margaret A. Lessenger

In Situ-Produced Cosmogenic Isotopes in Terrestrial Rocks, D. Lal

Time Variations of the Earth's Magnetic Field: From Daily to Secular, Vincent Courtillot and Jean Louis Le Mouël

Deep Slabs, Geochemical Heterogeneity, and the Large-Scale StRUCTURE OF MANTLE CONVECTION: Investigation of an Enduring Paradox, Paul G. Silver, Richard W. Carlson, and Peter Olson

United Plates of America, the Birth of a Craton: Early

Proterozoic Assembly and Growth of Laurentia, Paul F. Hoffman 
vi CONTENTS (continued)

Concepts and Methods of High-Resolution Event

STRATIGRAPHY, Erle G. Kauffman

605

INDEXES

Subject Index

655

Cumulative Index of Contributing Authors, Volumes 1-16 666

Cumulative Index of Chapter Titles, Volumes 1-16 